\title{
DIGLOSIA MASYARAKAT TUTUR PADA PENGGUNAAN BAHASA ARAB (KAJIAN KEBAHASAAN TERHADAP BAHASA FUSHA DAN BAHASA ‘AMIYAH DILIHAT DARI PERSPEKTIF SOSIOLINGUISTIK)
}

\author{
Widi Astuti \\ Dosen Tetap Program Studi Pendidikan Bahasa Arab \\ STAI Masjid Syuhada Yogyakarta \\ Email : Widychuby1990@gmail.com
}

\begin{abstract}
Abstrak
Tema tersebut penulis angkat berdasarkan fenomena bahasa yang beragam dimana bahasa yang dipakai tidak hanya satu meskipun penuturnya sama dan pada satu tempat / tinggal di lingkungan yang sama. Hal ini disebabkan oleh banyak faktor antara lain faktor fleksibilitas bahasa yang dipakai, faktor budaya dan kebiasaan, dan faktor-faktor diluar bahasa lainnya. Inti dari pembahasan ini antara lain adalah penjelasan mengenai maksud dari istilah diglosia, latarbelakang munculnya diglosia, dan beberapa contoh kosakata bahasa arab Fusha dan bahasa arab 'Amiyah yang muncul akibat dari diglosia.
\end{abstract}

Kata kunci: Diglosia, Bahasa Fusha, Bahasa 'Amiyah, Sosiolinguistik.

\section{Abstract}

The theme is the author of lift based on the phenomenon of a diverse language where the language used is not only one although the speakers are the same and in one place / live in the same environment. This is due to many faktors such as the faktor of language flexibility used, cultural and custom faktors, and faktors outside of other languages. The essence of this discussion includes an explanation of the meaning of the term diglossia, the background of the emergence of diglossia, and some examples of Arabic vocabulary of Fusha and Arabic 'Amiyah which arise as a result of diglossia.

Keywords: Diglosia, Fusha Language, 'Amiyah, Sociolinguistic. 
Widi Astuti : Diglosia Masyarakat Tutur pada Penggunaan Bahasa Arab

\section{A. Pendahuluan}

1. Latar Belakang Masalah

Diglosia adalah suatu situasi bahasa di mana terdapat pembagian fungsional atas variasi-variasi bahasa atau bahasa-bahasa yang ada di masyarakat. Maksud tersebut ialah bahwa terdapat perbedaan antara ragam formal atau resmi dan tidak resmi atau non-formal. Contohnya misalkan di Indonesia terdapat perbedaan antara bahasa tulis dan bahasa lisan.

Diglosia adalah sebuah penamaan yang diberikan pada gejala penggunaan dua ragam bahasa yang sebenarnya berasal dari satu bahasa induk dalam sebuah masyarakat pada waktu yang bersamaan. Fenomena diglosia dalam masyarakat Arab -sebagaimana dijelaskan sebelumnya- sudah terjadi sejak jaman jahili atau praIslam. Masing-masing kabilah memiliki bahasa tersendiri di samping lugat musytarakah, sebuah bahasa pergaulan yang dianut oleh berbagai kabilah yang ada. Bahasa bersama (lughat musytarakah) ini lahir sebagai akibat dari hubungan perdagangan antarkabilah, perjalanan menunaikan ibadah haji dan lawatan-lawatan. Komunikasi antarindividu dalam sebuah kabilah cukup menggunakan bahasa kabilahnya sendiri. Tetapi ketika berhubungan dan berkomunikasi dengan anggota kabilah lainnya mereka menggunakan bahasa pergaulan bersama itu.

Pernyataan diatas menjelaskan bahwa diglosia merupakan fenomena bahasa yang beragam dimana bahasa yang dipakai tidak hanya satu meskipun penuturnya sama dan pada satu tempat/tinggal dilingkungan yang sama. Hal ini disebabkan oleh banyak 
faktor antara lain faktor fleksibilitas bahasa yang dipakai, faktor budaya dan kebiasaan, dan faktor-faktor diluar bahasa lainnya.

Oleh karena itu, penulis tertarik untuk membahas tema tersebut dengan menyusun dan mengembangkan teori yang ada dengan realita yang terjadi saat ini. Dengan latarbelakangan masalah yang tealah disebutkan diatas penulis menyusun judul karya ilmiah tersebut menjadi Peristiwa diglosia dalam bahasa arab (kajian bahasa terhadap bahasa Fusha dan bahasa 'Amiyah dilihat dari perspektif sosiolinguistik)" untuk diulas pada pembahasan selanjutnya.

2. Rumusan masalah

Dari latarbelakang diatas timbul suatu pertanyaan antara lain sebagai berikut:

a. Apa yang dimaksud dengan istilah "diglosia"?

b. Apa saja latarbelakang diglosia tersebut muncul atau bisa terjadi?

c. Bagaimana peristiwa diglosia yang muncul dalam bahasa Arab?

d. Apa saja kosakata yang muncul akibat dari diglosia tersebut?

3. Tujuan penelitian

Berdasarkan rumusan diatas, penelitian ini disusun guna untuk mengetahui:

a. Mengetahui maksud dari istilah "diglosia".

b. Mengetahui latar belakang diglosia itu muncul dan bisa terjadi.

c. Mengetahui peristiwa diglosia yang muncul dalam bahasa Arab. 
Widi Astuti : Diglosia Masyarakat Tutur pada Penggunaan Bahasa Arab

d. Mengetahui kosakata yang muncul akibat dari diglosia.

\section{B. Pembahasan}

Kata diglosia berasal dari bahasa Prancis diglossie. Dalam pandangan Ferguson menggunakan istilah diglosia untuk menyatakan keadaan suatu masyarakat di mana terdapat dua variasi dari satu bahasa yang hidup berdampingan dan masing-masing mempunyai peranana tertentu. Jadi menurut Ferguson diglosia ialah suatu situasi kebahasaan relatif stabil, di mana selain terdapat jumlah dialek-dialek utama dari suatu bahasa terdapat juga ragam bahasa yang lain. diglosia/dig.lo $\cdot$ sia/n Ling situasi kebahasaan dengan pembagian fungsional atas variasi bahasa atau bahasa yang ada dalam masyarakat (misalnya ragam atau bahasa A untuk suasana resmi di kantor dan ragam atau bahasa B untuk suasana intim di rumah).

Diglosia adalah suatu situasi bahasa di mana terdapat pembagian fungsional atas variasi-variasi bahasa atau bahasa-bahasa yang ada di masyarakat. Yang dimaksud ialah bahwa terdapat perbedaan antara ragam formal atau resmi dan tidak resmi atau non-formal. Contohnya misalkan di Indonesia terdapat perbedaan antara bahasa tulis dan bahasa lisan.Agak mirip dengan kedwibahasaan, diglosia adalah penggunaan dua bahasa atau lebih dalam masyarakat, tetapi masing-masing bahasa mempunyai fungsi atau peranan yang berbeda dalam konteks sosial. Ada pembagian peranan bahasa dalam masyarakat dwibahasawan terlihat dengan adanya ragam tinggi dan rendah, digunakan dalam ragam sastra dan tidak, dan dipertahankan dengan tetap ada dua 
ragam dalam masyarakat dan dilestarikan lewat pemerolehan dan belajar bahasa.

Menurut Ferguson menggunakan istilah diglosia untuk menyatakan keadaan suatu masyarakat di mana terdapat dua variasi dari suatu bahasa yang hidup berdampingan dan masing-masing mempunyai peranan tertentu. Rumusan asli Ferguson tentang diglosia adalah :

Diglosia adalah suatu situasi kebahasaan yang relatif stabil, di mana selain terdapat sejumlah dialek-dialek-dialek utama (lebih tepat:ragam-ragam utama) dari satu bahasa, terdapat juga sebuah ragam lain. Dialek-dialek utama itu, di antaranya bisa berupa sebuah dialek standar, atau sevuah standar regional. Ragam lain (yang bukan dialek-dialek utama) itu memiliki ciri Sudah sangat terkodifikasi, Gramatikalnya lebih kompleks, Merupakan wahana kesusastraan tertulis yang sangat luas dan dihormati, Dipelajari melalui pendidikan formal, Digunakan terutama dalam bahasa tulis dan bahasa lisan formal, Tidak digunakan (oleh lapisan masyarakat manapun) untuk percakapan seharihari.

Ferguson membicarakan diglosia itu dengan mengambil contoh empat buah masyarakat tutur dengan bahasa mereka. Keempat masyarakat tutur itu adalah masyarakat tutur bahasa Arab, Yunani modern, Jerman Swiss, dan Kreol Haiti. Diglosia ini dijelaskan oleh Ferguson dengan mengetengahkan sembilan topik, yaitu fungsi, prestise, warisan sastra, pemerolehan, standarisasi, stabilitas, gramatika, leksikon, dan fonologi. Berikut kita bicarakan secara singkat.

Fungsi merupakan kriteria diaglossa yang sangat penting. Menurut ferguson dalam masyarakat diglosis 
terdapat dua variasi dari suatu bahasa, Variasi pertama disebut dialek tinggi (disingkat dialek $\mathrm{T}$ atau ragam $\mathrm{T}$ ), dan yang kedua disebut dialek rendah (disingkat dialek $\mathrm{R}$ atau Ragam R). Dalam bahasa Arab dialek T-nya adalah bahasa Arab klasik, bahasa Al5uran yang lazim disebut al-fusha, dialek R-nya adalah berbagai bentuk bahasa Arab yang digunakan oleh bangsa Arab, yang lazim disebut addarij. Dalam bahasa Yunani dialek T-nya disebut Katharevusa, yaitu bahasa Yunani murni dengan ciri-ciri linguistik Yunani klasik: Sedangkan dialek R-nya disebut dhimotiki, yakni bahasa Yunani Lisan. Dalam bahasa jerman-Swiss dialek T-nya adalah Jerman Standar, dan dialek R-nya adalah berbagai dialek bahasa Jerman. Di Haiti, yang menjadi dialek T-nya adalah bahasa Francis, sedangkan bahasa R-nya adalah bahasa Kreol-Haiti, yang dibuat berdasarkan bahasa Prancis.

Penggunaan dialek $\mathrm{T}$ atau $\mathrm{R}$ yang tidak cocok dengan situasinya menyebabkan si penutur bisa disoroti, mungkin menimbulkan ejekan, cemoohan, atau tertawaan orang lain. Sastra dan puisi rakyat memang menggunakan dialek $R$, tetapi banyak anggota masyarakat yang beranggapan bahwa hanya sastra/puisi dalam dialek T-lah yang sebenarnya karya sastra suatu bangsa. Dalam pendidikan formal dialek $\mathrm{T}$ harus digunakan sebagai bahasa pengantar, namun seringkali sarana kebahasaan menggunakan dialek R. Di Indonesia juga ada perbedaan ragam $T$ dan ragam $R$ bahasa Indonesia, ragam T digunakan dalam situasi formal seperti di dalam pendidikan; sedangkan ragam $\mathrm{R}$ digunakan dalam sistuasi nonformal seperti dalam pembicaraan dengan teman karib, dan sebagainya. 
Prestise. Dalam masyarakat diglosis para penutur biasanya menggunakan dialek $\mathrm{T}$ lebih bergengsi, lebih superior, lebih terpandang, dan merupakan bahasa yang logis. Sedangkan dialek $\mathrm{R}$ dianggap inferiror; malah ada yang menolak keberadaannya. Menurut Ferguson banyak orang Arab dan Haiti terpelajar menganjurkan agar dialek $\mathrm{R}$ tidak perlu digunakan, meskipun dalam percakapan sehari-hari mereka menggunakan dialek $\mathrm{R}$ itu. Anjuran golongan terpelajar Arab dan Haiti itu tentu merupakan kekeliruan, sebab dialek $\mathrm{T}$ dan dialek $\mathrm{R}$ mempunyai fungsinya masingmasing, yang tidak dapat dipertukarkan. Dalam masyarakat Indonesia pun ragam bahasa Indonesia baku dianggap lebih bergengsi daripada ragam bahasa Indonesia nonbaku. Dalam masyarakat Melayu/Indonesia beberapa puluh tahun yang lalu juga ada pembedaan bahasa Melayu T dan bahasa Melayu $\mathrm{R}$, di mana yang pertama menjadi bahasa sekolah, dan yang kedua menjadi bahasa pasar.

Warisan kesusastraan. Pada tiga dari empat bahasa yang digunakan Ferguson sebagai contoh terdapat kesusastraan di mana ragam $\mathrm{T}$ yang digunakan dan dihormati oleh masyarakat bahasa tersebut. Kalau ada juga karya sastra kontemporer dengan menggunakan ragam $\mathrm{T}$, maka dirasakan sebagai kelanjutan dari tradisi itu, yakni bahwa karya sastra harus dalam ragam $\mathrm{T}$. Tradisi kesusastraan yang selalu dalam ragam $\mathrm{T}$ ini (setidaknya dalam empat contoh diatas) menyebabkan kesusastraan itu menjadi asing dari masyarakat umum. Namun, kesusastraan itu menjadi asing dari masyarakat umum. Namun, kesusastraan itu tetap berakar, baik di negara-negara berbahasa Arab, bahasa 
Yunani, bahasa Prancis di Haiti, dan Bahasa Jerman di Swiss yang berbahasa Jerman.

Pemerolehan. Ragam $\mathrm{T}$ diperoleh dengan mempelajarinya dalam pendidikan formal, sedangkan ragam $\mathrm{R}$ diperoleh dari pergaulan dengan keluarga dan teman-teman sepergaulan. Oleh karena itu, mereka yang tidak pernah memasuki dunia pendidikan formal tidak akan mengenal ragam $\mathrm{T}$ sama sekali. Mereka yang mengenal ragam $\mathrm{T}$ hampir tidak pernah menguasai dengan lancar, selancar penguasaannya terhadap ragam $\mathrm{R}$. Alasannya, ragam $\mathrm{T}$ tidak selalu digunakan, dan dalam mempelajarinya selalu terkendali dengan berbagai kaidah dan aturan tata bahasa; sedangkan ragam $R$ digunakan secara reguler dan terus menerus di dalam pergaulan sehari-hari. Dalam masyarakat diglosis banyak orang terpelajar menguasai dengan baik kaidah-kaidah ragam $\mathrm{T}$, tetapi tidak lancar menggunakan ragam tersebut. Sebaliknya, mereka tidak tahu atau tidak pernah memperhatikan kaidah-kaidah tata bahasa ragam $\mathrm{R}$, teapi dengan lancar mereka dapat menggunakan ragam tersebut. Dalam beberapa masyarakat diglosis malah banyak penutur yang mengatakan bahwa ragam $\mathrm{R}$ tidak punya tata bahasa.

Standarisasi. Karena ragam $\mathrm{T}$ dipandang sebagai ragam yang bergengsi, maka tidak mengherankan kalau standarisasi dilakukan terhadap ragam $\mathrm{T}$ tersebut melalui kodifikasi formal. Kamus, tata bahasa, petunjuk lafal, dan buku-buku kaidah untuk penggunaan yang benar ditulis untuk ragam $T$. Sebaliknya, ragam $\mathrm{R}$ tidak pernah diurus dan diperhatikan. Jarang ada kajian yang menyinggung adanya ragam $\mathrm{R}$, atau kajian khusus mengenai ragam $\mathrm{R}$ tersebut. Kalau pun ada biasanya dilakukan oleh peneliti dari masyarakat bahasa lain, 
dan ditulis dalam bahasa lain. Sebagai ragam yang dipilih, yang distandarisasikan, maka ragam $\mathrm{T}$ jelas akan menjadi ragam yang lebih bergengsi dan dihormati.

Stabilitas. Kestabilan dalam masyarakat diglosis biasanya telah berlansung lama di mana ada sebuah variasi bahasa yang dipertahankan eksistensinya dalam masyarakat itu. Pertentangan atau perbedaan antara ragam $\mathrm{T}$ dan ragam $\mathrm{R}$ dalam masyarakat diglosis selalu ditonjolkan karena adanya perkembangan dalam bentuk-bentuk campuran yang memiliki ciri-ciri ragam $T$ dan ragam $R$. Peminjaman unsur leksikal ragam $\mathrm{T}$ ke dalam ragam $\mathrm{R}$ bersifat biasa; tetapi penggunaan unsur leksikal ragam $\mathrm{R}$ dalam ragam $\mathrm{T}$ kurang begitu biasa, sebab baru digunakan kalau sangat terpaksa.

Gramatika. Ferguson berpandangan bahwa ragam $\mathrm{T}$ dan ragam $\mathrm{R}$ dalam diglosia merupakan bentuk-bentuk dari bahasa yang sama; namun, di dalam gramatika ternyata banyak perbedaan. Umpamanya, dalam bahasa Jerman standar kita dapati empat kasus nomina dan dua tenses indikatif sederhana; sedangkan dalam bahasa Jerman Swiss hanya terdapat tiga kasus nomina, dan satu tenses sederhana. Nomina bahasa Prancis menunjukan agreement dalam jumlah dan jenis (gender), sedangkan nomina KreolHaiti tidak memiliki hal iyu. Dalam ragam $\mathrm{T}$ adanya kalimatkalimat kompleks dengan sejumlah konstruksi subordinasi adalah hal yang biasa, tetapi dalam ragam $\mathrm{R}$ dianggap artifisial.

Leksikon. Sebagian besar kosakata pada ragam $\mathrm{T}$ dan ragam $R$ adalah sama. Namun, ada kosakata pada ragam $T$ yang tidak ada pasangannya pada ragam $R$, atau sebaliknya, ada kosakata pada ragam $R$ yang tidak ada pasangannya pada 
Widi Astuti : Diglosia Masyarakat Tutur pada Penggunaan Bahasa Arab

ragam T. Ciri yang paling menonjol pada diglosia adalah adanya kosakata yang berpasangan, satu untuk ragam $\mathrm{T}$ dan satu untuk ragam $R$, yang biasanya untuk konsep=konsep yang sangat umum. Umpamanya, dalam bahasa Yunani "rumah" untuk ragam $\mathrm{T}$ adalah ikos dan untuk ragam $\mathrm{R}$ adalah spiti. Dalam bahasa Arab "Apa" untuk ragam T adalah ma dan untuk ragam $\mathrm{R}$ adalah eh. Menurut Ferguson dalam masyarakat diglosis hanya kosakata ragam $\mathrm{T}$ yang bisa ditulis secara formal; dan hanya ragam $\mathrm{R}$ yang hanya diharapkan dalam percakapan sehari-hari. Dalam bahasa Indonesia kita pun dapat mendaftarkan sejumlah kosakata yang berpasangan sebagai kata baku dan tidak baku. Antara lain, uang dan duit, buruk dan jelek, istri dan bini.

Fonologi. Dalam bidang fonologi ada perbedaan struktur antara ragam $\mathrm{T}$ dan ragam $\mathrm{R}$. Perbedaan tersebut bisa dekat bisa juga jauh. Ferguson menyatakan sistem bunyi ragam $T$ dan ragam $\mathrm{R}$ sebenarnya merupakan sistem tunggal; namun, fonologi $\mathrm{T}$ merupakan sistem dasar, sedangkan fonologi $\mathrm{R}$, yang beragam-ragam, merupakan subsistem atau parasistem. Fonologi T lebih dekat dengan bentuk umum yang mendasari dalam bahasa secara keseluruhan. Fonologi R lebih jauh dari bentuk-bentuk yang mendasar.

Menurut Fishman pengertian diglosia tidak terbatas pada dua ragam dari satu bahasa, tetapi diacukan pada situasi dimana terlihat perbedaan-perbedaan yang jelas dalam system linguistic yang disebabkan karena fungsi-fungsi social. Diglosia adalah suatu situasi bahasa yang relative stabil dimana, selain dialek-dialek utama satu bahasałyang mungkin mencakup satu bahasa baku atau bahasa-bahasa baju ragional\}, ada ragam bahasa yang sangat berbedA, sangat 
terkodifikasi \{seringkali secara gramatik lebih komplek\} dan lebih tinggi, sebagai wahana dalam keseluruhan kesustraan tertulis yang luas dan dihormati, baik pada kurun waktu terdahulu maupun pada masyarakat ujaran lain yang banyak dipelajari lewat pendidikan formal dan banyak dipergunakan dalam tujuan-tujuan tertulis dalam ujaran resmi, tapi tidak dipakai oleh bagian masyarakat apapun dalam pembicaraanpembicaraan biasa. Atau diglosia dapat diartikan juga sebagai hadirnya dua bahasa baku dalam satu bahasa, bahasa "tinggi" dipakai dalam suasana-suasana resmi dan dalam wacana-wacana tertulis, dan bahasa "rendah" yang dipakai dalam percakapan sehari-hari.

Ada pendapat lain bahwa Istilah diglosia ini pertama kali digunakan dalam bahasa Perancis diglossie yang diserap dari bahasa Yunani, 'dwibahasa') oleh bahasawan Yunani Ioannis Psycharis. Ahli bahasa Arab William Marçais lalu juga menggunakannya pada tahun 1930 untuk menuliskan situasi bahasa di dunia Arab.Diglosia adalah suatu situasi bahasa di mana terdapat pembagian fungsional atas variasi-variasi bahasa atau bahasa-bahasa yang ada di masyarakat. Yang dimaksud ialah bahwa terdapat perbedaan antara ragam formal atau resmi dan tidak resmi atau non-formal.

Menurut Fishman ada empat hubungan antara bilingualitas dan diglosia, diantaranya: 1) Diglosia dan Bilingualisme: adanya dua bentuk bahasa dalam masyarakat. Distribusi yang stabil atau tetap dari variasi-variasi bahasa sesuai dengan fungsi sosialnya, dan adanya dua bahasa. 2) Diglosia tanpa Bilingualisme: Dalam masyarakat bahasa ini terdapat perbedaan fungsional yang ketat dari ragam-ragam bahasa sesuai T dan R. Dalam kebanyakkan hal kasus ini 
Widi Astuti : Diglosia Masyarakat Tutur pada Penggunaan Bahasa Arab

adalah perilaku anatar kelompok dari kekuatan yang berkuasa \{ragam $\mathrm{T}\}$, yang bukan hanya hidup jauh dari orangorang biasa, tetapi sengaja membedakan bahasa mereka dari orang-orang kebanyakkan. Kasus ini sering ditemukan dalam masyarakat yang pernah dijajah. 3) Bilingualisme tanpa Diglosia: Kita ketahui bahea diglosia ditandai dengan distribusi fungsi social yang berbeda-beda sesuai dengan suasana individual maupun sosial. Jadi bilingualisme bervariasai sesuai dengan situasi, peran, topic, dan tujuan komunikasi. Dengan demikian dalam kebanyakkan masyarakat banyak ditemukan kasus bilingualisme tanpa diglosia. Situasi semacam ini tidaklah stabil, tapi bergantung pada perubahan sebagai akibat adanya korelasi dengan parameter-parameter social yang sangat bervariasi. 4) Tanpa Bilingaulisme dan Diglosia: Jenis ini dari masyarakat bahasa yang terisolasi yang tidak banyak berhubungan dengan dunia luar.

Fasold mengembangkan konsep diglosia ini menjadi apa yang disebutkan broad diglosia (diglosia luas). Dalam konsep broad diglosia perbedaan itu tidak hanya antara dua bahasa atau dua ragam atau dua dialek secara biner, melainkan bisa lebih dari dua bahasa atau dua dialek itu. Dengan demikian termasuk juga keadaan masyarakat yang di dalamnya ada diperbedakan tingkatan fungsi kebahasaan, sehingga munculah apa yang disebut Fasold diglosia ganda dalam bentuk yang disebut double overlapping diglosia, double-nested diglosia, dan linear polyglosia.

Double overlapping diglosia adalah adanya situasi pembedaan derajat dan fungsi bahasa secara berganda. Contoh keadaan semacam ini bisa kita temukan di negara 
Tanzania, dimana di negara tersebut digunakan Bahasa Inggris, Swahili dan beberapa bahasa daerah. Pada satu saat tertentu Bahasa Swahili merupakan ragam $\mathrm{H}$ dimana ragam Lnya adalah bahasa-bahasa daerah. Di situasi yang berbeda, Bahasa swahili menjadi ragam L dan Bahasa Inggris berperan sebagai ragam H. Double-nested diglosia adalah keadaan dalam masyarakat multilingual, terdapat dua bahasa yang diperbedakan satu sebagai ragam $\mathrm{H}$, dan yang lain sebagai ragam L. Fenomena semacam ini ditemukan di desa Khalapur, salah satu desa di India. Di desa tersebut terdapat dua macam bahasa yang digunakan, yakni Bahasa Khalapur dan Bahasa Hindi. Bahasa Khalapur sebagai bahasa daerah memiliki ragam $\mathrm{H}$ dan $\mathrm{L}$. Begitu pula dengan Bahasa Hindi yang digunakan juga memiliki ragam $\mathrm{H}$ dan $\mathrm{L}$.

Linear polyglosia bisa tergambarkan dengan jelas pada masyarakat Cina Malaysia. Pada masyarakat Cina Malaysia yang terpelajar dan mampu berbahasa Inggris, Bahasa Melayu ragam $\mathrm{H}$, yaitu bahasa Malaysia merupakan variasi linguistik tertinggi kedua yang digunakan dalam masyarakat itu. Bahasa Melayu informal yang disebut bahasa Melayu Bazar mempunyai kedudukan yang sangat rendah, berada di bawah bahasa manapun. Bahasa Inggris dan variasi bahasa Cina kedudukannya lebih tinggi dari bahasa Melayu Bazar ini. Di samping itu terdapat bahasa Cina Mandarin yang mempunyai kedudukan khusus, dan harus dimasukkan dalam deretan khasanah bahasa tersebut.

Latar belakang munculnya diglosia antara lain adalah sebagai berikut:

Sebagaimana dijelaskan sebelumnya, bahasa Arab baku adalah bahasa Quraisy yang digunakan Al-Qur'an dan nabi 
Widi Astuti : Diglosia Masyarakat Tutur pada Penggunaan Bahasa Arab

Muhammad Saw. Bahasa ini selanjutnya disebut sebagai bahasa Arab fusha. Hari ini bahasa Arab fusha adalah ragam bahasa yang ditemukan di dalam Al-Qur'an, hadis Nabi dan warisan tradisi arab. Bahasa fusha hari ini digunakan dalam kesempatan kesempatan resmi dan untuk kepentingan kodifikasi karya-karya puisi, prosa dan penulisan pemikiran intelektual secara umum (Ya'kub, 1982:144).

Sedangkan bahasa amiyah adalah ragam bahasa yang digunakan untuk urusan-urusan biasa sehari-hari. Bahasa amiyah ini, menurut kalangan linguis modern, dikenal dengan sejumlah nama, semisal; al-lughat alamiyah, al-syakl allughawi al-da:rij, al-lahjat al-sya'i'ah, al-lughat almahkiyah, allahjat al-Arabiyah al-amiyah, al-lahjat al-da:rijah, al-lahjat alamiyah, al-Arabiyah al-amiyah, al-lughat al-da:rijah, al-kala:m al-da:rij, al-kalam al-ami, dan lughat al-sya'b.

Pada jaman jahiliah atau pra-Islam masyarakat memiliki bermacam-macam dialek akibat perbedaan tempat tinggal dan kebutuhan sosial-budaya masingmasing kabilah. Pada gilirannya, dipelopori oleh kabilah Quraisy yang memiliki kekuasaan politik, ekonomi dan agama, seluruh kabilah Arab dapat merumuskan lingua franca yang dijadikan bahasa lintas kabilah. Lingua franca antarkabilah Arab di jaman pra-Islam itu adalah bahasa fusha. Meskipun demikian dialek-dialek kabilah masih diakui keberadaannya, dan tidak disebut sebagai lahn atau penyimpangan bahasa, Setelah datangnya Islam, masyarakat Arab lebih suka menggunakan bahasa fusha yang digunakan oleh Al-Qur'an dan hadis Nabi, dalam rangka makin memperkokoh persatuan antarmereka. Sejak jaman Nabi Muhammad dan para sahabat Khulafaur Rasyidin sudah ditemui fenomena lahn atau penyimpangan berbahasa 
dalam bentuknya yang paling sederhana, yaitu kesalahan dalam i'rab.

Sejak dilakukannya ekspansi Islam ke luar jazirah Arab dan masyarakat Arab mulai berinteraksi dengan orang ajam (non-Arab) maka terjadi penyimpangan bahasa yang semakin meluas, tidak saja dalam bahasa lisan tetapi juga bahasa tulis. Untuk mengantisipasi meluasnya lahn itu mulai diletakkan dasar-dasar tata bahasa Arab (nahw). Munculnya ilmu nahwi itu tetap tidak kuasa membendung perkembangan lahn sehingga melahirkan dialek-dialek (lokal) baru yang otonom yang disebut bahasa amiyah dengan kaidahkaidahnya sendiri.

Pada jaman moderen di dalam masyarakat Arab gejala diglosia menjadi hal yang harus diterima, dengan adanya dua ragam bahasa Arab yang memiliki perbedaan cukup siginifikan sehingga menimbulkan berbagai masalah dalam berbagai bidang, Karena bahasa amiyah dianggap lebih mudah, fleksibel dan aktual dibanding bahasa fusha maka timbullah seruan untuk menggunakannya dan meninggalkan bahasa fusha. Seruan ini memperoleh perlawanan sengit dari sebagian masyarakat (bahkan jumlahnya mungkin lebih besar) yang mendukung pelestarian bahasa fusha sebagai bahasa agama dan bahasa persatuan.

Untuk mengatasi masalah itu perlu dilakukan perbaikan dalam hal pembelajaran bahasa Arab secara umum, khususnya mengenai penyajian tata bahasa Arab fusha yang lebih disederhanakan, memperbaiki strategi dan media pembelajarannya, memperbanyak buku-buku bacaan sederhana untuk anak dalam berbagai bidang dalam bahasa fusha, dan lain sebagainya. 
Kosakata bahasa arab yang mengalami diglosia antara lain adalah berikut ini:

Perbedaan antara Fusha dan Amiyah yaitu terdapat pada kaidah-kaidah nahwu dan Sharf, bahasa Arab Fusha sangat memperhatikan pada kaidah kaidah nahwu dan sharf, sedangkan bahasa Arab Amiyah tidak memperhatikan pada hal tersebut. Maka dari itu penggunaan bahasa Arab Fushay dan Amiah digunakan pada forum yang juga berbeda. Bahasa Arab Fusha digunakan pada forum-forum dan media-media yang bersifat formal. Sebaliknya, bahasa Arab Amiyah sering digunakan dalam aktivitas dan komunikasi sehari-hari yang bersifat non formal.

Beberapa perbedaan diantara bahasa Arab Fusha dan Arab Amiyah antara dalam "قُطنا" (pengucapan) dan "äها" (logat) dan bahkan dalam ""لاغं (bahasa) itu sendiri. Bahasa Arab Fusha mempunyai bentuk yang sama di beberapa negara negara dunia. Sehingga, orang yang saling berbicara dengan berbahasa Arab Fusha akan memahami maksud dari yang disampaikan walaupun orang-orang tersebut mempunyai latar belakang yang berbeda.

Berbeda dengan bahasa Arab Amiyah, Bahasa Arab Amiyah

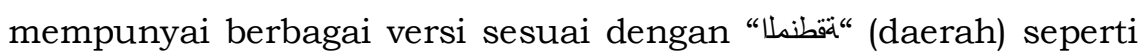
negara Arab dan Mesir mempunyai bahasa Arab Amiah yang berbeda diantara keduanya dan begitu pula terhadap bahasa Amiah Mesir dan Jordan. Sebagai contoh; 
Widi Astuti : Diglosia Masyarakat Tutur pada Penggunaan Bahasa Arab

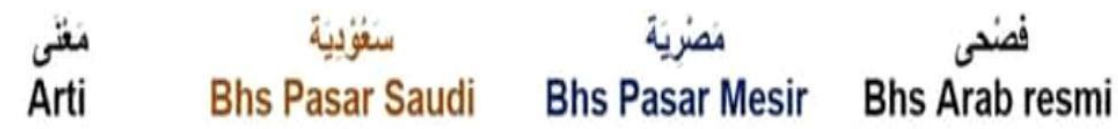

\begin{tabular}{|c|c|c|c|}
\hline Selamat atas kalian & 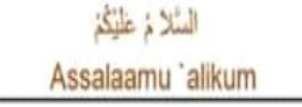 & 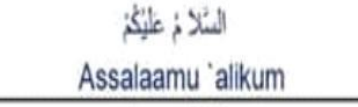 & 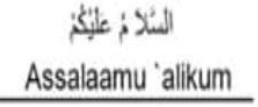 \\
\hline \multirow[t]{2}{*}{ Selamat datang } & أنلاز سنيلا & 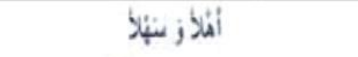 & أنلاز سئلا \\
\hline & Ahlan wasahlan & Ahlan wasahlan & Ahlan wasahlan \\
\hline \multirow[t]{2}{*}{ Selamat pagi } & صبَّاخ الخئي & هنباخ: الثنال & 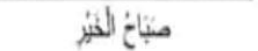 \\
\hline & Shabaahul khair & Shabaahul fuul & Shabaahul khair \\
\hline \multirow[t]{2}{*}{ Selamat sore } & نسأة الخيز & مشتأ الخئر & 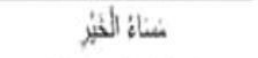 \\
\hline & Masaa ul kher & Masaa ul kher & Masaa ul khair \\
\hline \multirow[t]{2}{*}{ Selamat tidur } & 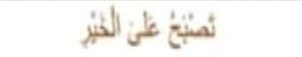 & 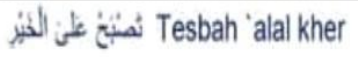 & 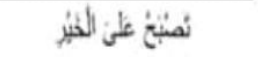 \\
\hline & Tesbah 'alal kher & & Tasbahu 'alal khair \\
\hline Selamat ( hari-hari & 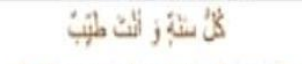 & 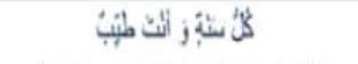 & 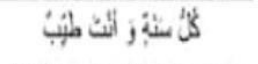 \\
\hline \multirow{2}{*}{$\begin{array}{c}\text { besar, "led, tahun baru. } \\
\text { Ultah) }\end{array}$} & Kullu sanah winta thayyib & Kullu sanah wenta thayyib & Kullu sanatin wa anta \\
\hline & & & thayyib \\
\hline \multirow[t]{2}{*}{ Cepat! } & برز" & بسز" بن & بلز" بلة \\
\hline & Bisurah & Bisurah & Bisuratin \\
\hline \multirow[t]{2}{*}{ Pelan-pelan! } & بالمُرْْن & بالزأة & بلأزاذة \\
\hline & Bisweys & Birraha & Birraahati \\
\hline \multirow[t]{2}{*}{ Apa ini? } & 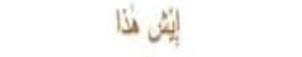 & 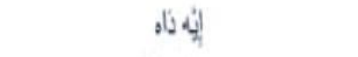 & 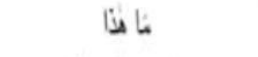 \\
\hline & Iysy haadza & Ee daa & Maa haadza \\
\hline \multirow{2}{*}{$\begin{array}{c}\text { Tidak apa-apa, Tidak } \\
\text { ada masalah }\end{array}$} & ما في ستبكة & 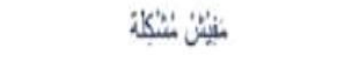 & 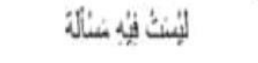 \\
\hline & Maa fil musykilah & Mafiisy Musykilah & Laysat filhi mas alatun \\
\hline \multirow[t]{2}{*}{ Mau apa kau? } & إئل نئنغ & ماللا إلث & مادَانُربّة \\
\hline & Iysy tebgha & Inta Maa lak & Maadza turiidu \\
\hline \multirow[t]{2}{*}{ Biarkan saya sendiri } & 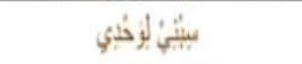 & 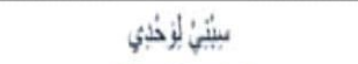 & 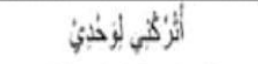 \\
\hline & Sibni liwahdi & Sibni liwahdi & Utrukni liwahdii \\
\hline \multirow[t]{2}{*}{ Hati-hati! } & افُشرن & خلى بالك & 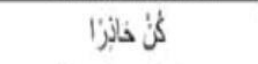 \\
\hline & Intaris & Khalli baalak & Kun haadziran \\
\hline \multirow[t]{2}{*}{ Tidak mungkin } & 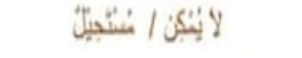 & 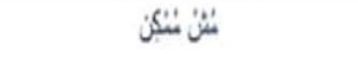 & 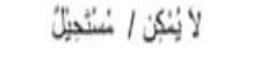 \\
\hline & La yumkin / mustahiil & Musy mumkin & La yumkin / mustahiil \\
\hline
\end{tabular}


Widi Astuti : Diglosia Masyarakat Tutur pada Penggunaan Bahasa Arab

\section{Penutup}

Berdasarkan pembahasan diatas dapat disimpulkan bahwa diglosia adalah suatu situasi bahasa di mana terdapat pembagian fungsional atas variasi-variasi bahasa atau bahasa-bahasa yang ada di masyarakat. Maksud tersebut ialah bahwa terdapat perbedaan antara ragam formal atau resmi dan tidak resmi atau non-formal. Contohnya misalkan di Indonesia terdapat perbedaan antara bahasa tulis dan bahasa lisan. Perbedaan antara Fusha dan Amiyah yaitu terdapat pada kaidah-kaidah nahwu dan Sharf, bahasa Arab Fusha sangat memperhatikan pada kaidah kaidah nahwu dan sharf, sedangkan bahasa Arab Amiyah tidak memperhatikan pada hal tersebut. Maka dari itu penggunaan bahasa Arab Fusha dan Amiah digunakan pada forum yang juga berbeda. Bahasa Arab Fusha digunakan pada forum-forum dan mediamedia yang bersifat formal. Sebaliknya, bahasa Arab Amiyah sering digunakan dalam aktivitas dan komunikasi sehari-hari yang bersifat non formal. 


\section{DAFTAR PUSTAKA}

Alwasilah, A.Chaedar. 1985. Sosiologi Bahasa. Bandung. Angkasa

Ar-Rajihi, A. 1979. Figh al-Lughah fi-l Kutub al-Arabiyah. Beirut: Dar alNahdhah

Aslinda dan Syafyahya Leni. 2007. Pengantar Sosiolinguistik.Bandung PT.ReplikaAditama

Chaer, Abdul. 1995. Sosiolinguistik Perkenalan awal. Jakarta. Rineka Cipta

Hudson,R.A. 1998. Sosiolinguistik. Saduran. E.Suryatin.Bandung. Amal Keluarga

Nababan, P.W.J. 1984. Sosiolinguistik Suatu pengantar. Bandung. Gramedia

Suwito. 1983. Sosiolinguistik:Teori dan Problema. Surakarta. Henary offset

Tohe, Bahasa Arab Fusha dan Amiyah. BAHASA DAN SENI, Tahun 33, Nomor 2, Agustus 2005 